\title{
O bem comum na obra de David Hollenbach
}

\author{
Orientador: Mario de França Miranda \\ Doutorando: Edson Donizete Toneti \\ Área de Concentração: Teologia Sistemático-Pastoral \\ Linha de Pesquisa: Fé e Cultura
}

Esta tese tem como objetivo recuperar um enfoque ético sobre o bem (comum), porém dentro dos contextos sociais e eclesiais contemporâneos. David Hollenbach é o autor estudado neste trabalho, especialmente porque ele tenta responder a questões importantes como o papel da religião na vida pública, o conceito tradicional de tolerância e individualismo em uma sociedade pluralista e outros problemas contemporâneos sobre relacionamento em comunidade. Este estudo é estruturado em três capítulos. O primeiro capítulo é uma análise da situação atual, caracterizada pelo pluralismo, o individualismo e a tolerância, cuja abordagem é ineficaz para lidar com a pobreza urbana nos Estados Unidos. O segundo capítulo estabelece um quadro teórico para o bem comum, com base em bens sociais, o papel público da religião, as contribuições teológicas de Agostinho e Tomás de Aquino, e da solidariedade intelectual. O último capítulo é uma leitura de questões práticas à luz da teoria do bem comum.

A reafirmação da antiga tradição do bem comum, um valioso conceito para o pensamento social cristão, de tal forma que contribua para lidar com as divisões sociais da vida urbana contemporânea e da sociedade global é o principal objetivo. Hollenbach baseia-se em análise social, filosofia moral e ética teológica para traçar novos rumos que possibilitem a consecução do bem comum para todos os americanos. Os problemas dedivisão entrea classe média e os pobres nas grandes cidades e outros desafios exigem um novo compromisso com o bem comum. A tolerância não é parâmetro para pautar este tipo de relacionamento. Ademais, o individualismo, profundamente arraigado na cultura americana, dificulta a consecução do bem comum. Para tanto, a leitura de Tomás de Aquino e Agostinho, na ética cristã de Hollenbach, convoca crentes e não crentes para se moverem em direção a novas formas de solidariedade, caso queiram viver juntos uma vida boa. Uma ressignificação teórica do bem comum permite fazer contribuições práticas às mais variadas abordagens de ordem política, social, cultural, religiosa em sua dinâmica de desenvolvimento.

Palavras-chave: Bem comum, pluralismo, religião. 